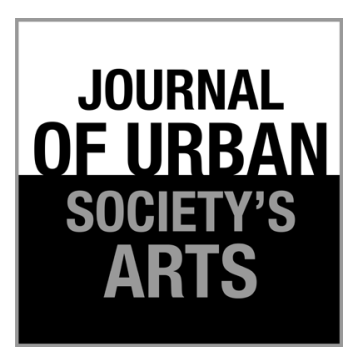

Volume 4 Nomor 2, Oktober 2017: 71-88

\section{Drawing Maps for Research in Creative Writing through $\mathrm{A} / \mathrm{r} /$ tography}

\author{
Chrysogonus Siddha Malilang
}

University of Macau

\section{ABSTRACT}

The return of Creative Writing to the academia was intended as an answer to rigid approaches employed in the nineteenth century's teaching of English Literature. This comeback has since brought back a new perspective in seeing body of literature as a living body but at the same time also introduced clash between dominating research paradigm in the academia. The writers who were hired to teach creative writing tended to prioritise their creative practice, while the general consensus in academia called for more theoretical-oriented research. In order to compromise, the practice-based research method was born.

Despite various justifications that creative process is the same as research inquiry, the heavier emphasis on creative works in this method still invites criticism, such as the lack of research rigour (Biggs \& Büchler, 2007). New framework to balance and bridge practice and research rigour is thus needed - especially one that can accommodate the non-linear thinking trajectories in creative practices. Due to the possible non-linearity, the new research platform should not follow the reigning 'arborescent scheme' in the academic research tradition, but incorporate the concept of Deleuzian rhizome.

$\mathrm{A} / \mathrm{r} /$ tography - developed based on the premise of art and art creation as a rhizomatic process/activity-is proposed as one of the potential practices for creative writing research. The non-linear view of $\mathrm{a} / \mathrm{r} /$ tography towards arts practices suggests a rhizomatic role in the mapping of creative writing process. As it addresses and accommodates multiplicities, $\mathrm{a} / \mathrm{r} /$ tography also facilitates non-native English speakers to conduct and map his journey in art creation and research inquiry. Author's project of writing a collection of bilingual poems based on classical Javanese song cycle-Sekar Macapat-is presented to illustrate the claim.

Keywords: research; creative writing; a/r/tography

\begin{abstract}
ABSTRAK
Pemetaan untuk Penelitian Mengenai Penulisan Kreatif melalui A/r/tography. Kembalinya Penulisan Kreatif ke akademisi dimaksudkan sebagai jawaban atas pendekatan kaku yang digunakan dalam pengajaran Sastra Inggris abad kesembilan belas. Kembalinya ini sejak itu membawa kembali perspektif baru dalam melihat tubuh sastra sebagai makbluk hidup namun pada saat bersamaan juga mengenalkan bentrokan antara paradigma penelitian yang mendominasi di kalangan akademisi. Penulis yang dipekerjakan untuk mengajarkan penulisan kreatif cenderung memprioritaskan praktik kreatif mereka, sementara konsensus umum di akademisi meminta penelitian yang berorientasi teoritis. Agar kompromi, metode penelitian berbasis praktik labir.

Terlepas dari berbagai pembenaran bahwa proses kreatifsama dengan penelitian penelitian, penekanan yang lebih berat pada karya kreatif dalam metode ini masih mengundang kritik, seperti kurangnya ketelitian penelitian (Biggs \& Büchler, 2007). Kerangka kerja baru untuk menyeimbangkan dan menjembatani praktik dan ketelitian penelitian diperlukan-terutama yang dapat mengakomodasi lintasan pemikiran non linier dalam praktik kreatif. Karena kemungkinan non-linearitas, platform penelitian baru tidak boleh mengikuti skema árborescent' yang berkuasa dalam tradisi penelitian akademis, namun menggabungkan konsep rimpang Deleuzian.
\end{abstract}




\begin{abstract}
$\mathrm{A} / \mathrm{r} /$ tography - dikembangkan berdasarkan premis penciptaan seni dan seni sebagai proses/kegiatan rhizomatic- diusulkan sebagai salah satu praktik potensial untuk penelitian penulisan kreatif. Pandangan non-linear $\mathrm{a} / \mathrm{r} /$ tography terhadap praktik seni menunjukkan peran rhizomatic dalam pemetaan proses penulisan kreatif. Karena membahas dan mengakomodasi keragaman, a/r/tography juga memfasilitasi penutur asli non-bahasa Inggris untuk melakukan dan memetakan perjalanannya dalam pembuatan seni dan penyelidikan penelitian. Proyek penulis untuk menulis kumpulan puisi bilingual berdasarkan siklus lagu Jawa klasik-Sekar Macapat-disajikan untuk menggambarkan klaim tersebut.
\end{abstract}

Kata kunci: penelitian; penulisan kreatif; a/r/tography

\section{Introduction}

What we think of now as creative writing arises from the long-standing tradition of story making. Stories, both the orally transmitted and written down, play important roles in the course of human history. Nobody can honestly overlook the contribution of Homer, Shakespeare, or Basho in the journey and the advancement of human civilization. Their works are seen as milestones for their era and culture, placing them in special places within the collective memory. Some others, albeit not as highly venerated as them, are also notable for their significant roles in facilitating or paving a way to major changes or shake-ups in the history. Harriet Beecher Stowe's Uncle Tom Cabin, if one is to exemplify a later influential book, has been acknowledged as one of the triggers for American Civil War in the nineteenth century. One cannot dismiss easily the effect of this unrest, as it ushered in the new era of equality in United States of America.

From the far eastern part of the world, The Philippines' Jose Rizal has been acknowledged in Benedict Anderson's seminal text, Imagined Communities (1991), as the seed for 'national/collective imagination' for that country. The aforementioned text fueled the fighting spirit for their independence. In a similar manner, Douwes Dekker's Max Havelaar had the rippling effects on Indonesia's fight for independence from the colonial Dutch. In response to Dekker's critiques in the novel, the Dutch implemented their ethical policy, bringing about education to the inlanders in East Indies (what would be modern-day Indonesia). This policy led to the birth of more educated elites who became the motor for unified fight for independence.

What Stowe, Rizal, and Dekker achieved through their writing reveals the potential power in creative writing. The texts did not tell people to start moving. They are not overt manuals or provocation to fight. It was just a start, a small ripple that led into a bigger wave. Webb and Brien (2008), reflecting on this phenomenon, refer to creative arts and writing as the fountain of knowledge. Despite the lack of overt didacticism within them, creative works are capable to spark critique and interpretation leading into the formation of new insights. "[T] he knowledge generated by an artwork, and the interpretation that emerges from it, are traditionally found not in the work itself, but in review, analyses and other critical writings that interpret it." \{ibid, no page).

While it is easy to see the knowledge generated from the creative writing as a product being researched upon, the case of research on creative writing as a process still triggers countless debates and clashes. Academia is divided into two research polarities regarding this topic. One side favours a more academic form of research and the other favours heavier focus on the creative acts / practices. This article aims to (1) review the history of Creative Writing and how the schism was formed, (2) review and promote $\mathrm{a} / \mathrm{r} /$ tography as a possible research method / practice to bridge the schism through the (3) exemplification of the practice and how it can be used to answer the challenge of creative writing in the multicultural world. 


\section{How Creative Writing Enters Academia}

Although story making activities have always been a part of human civilization, the formal acknowledgement to Creative Writing in the dictionary did not happen until much later. Monteith (1992: 11) noted that creative writing was only first mentioned and featured in the 1922 edition of Oxford English Dictionary. It was not until 1930 that the first published academic article on creative writing appeared in English Journal. Referring to the fact that English Journal is an American publication, Monteith highlights America as the birthplace of Creative Writing in the academic context.

D.G. Myers' (2006) attempt to chronicle the birth of Creative Writing in academia traces the history back to as early as the $19^{\text {th }}$ century America. It perhaps more appropriate to refer to this as the returning point, as Webb and Brienn (2008) claimed that creative practices, including creative writing, could be found as a part of early European university system. Looking further at the root word for 'university', Encyclopædia Brittanica noted that universitas originally refers to the scholastic guild or community - the corporation of students and masters. This form allows the inclusion of creative practices to be taught and learn as apprenticeship learning from more established craftmaster/artists (Calhoun \& Sennet, 2008: 5 - 6; Sennet, 2007: 8-11; Lave \& Wenger, 1991: 27 - 34).

The dawn of Enlightenment era, as Webb and Brien (2008: 1) argue, brought about reduction of art into "a ratio inferior", the science of the sensate. Art was seen as related to logic - a concept championed by Enlightenment and Cartesian view - but only an inferior type. Deemed unfit to compete with other more logical subjects, creative practices were relegated into the back seats of academic system.

The disappearance of creative practices left the university system with an open gap in the coverage of arts and other creative-related production. Classic Study was appointed to fill in this void (Harper \& Kroll, 2008: 1; Hobsbaum, 1992: 24 26; Monteith, 1992: 12 - 15; Mayers, 2009; Myers, 1993; 2006: 4). The study, as its name suggests, focused on texts written mainly in Ancient Greek and Latin. While this step had opened up a space to study and discuss arts and literature, the nature of studied texts did not allow study and discussion of more contemporary works. With the spirit of 'pure reason' as the core of education reform, students in Classic Study were prepared more on the understanding, interpreting and writing critique for the texts. The focal point was texts as the product and next to no emphasis to the writing process.

Between late 1860 s to the early 1890 s, the interest in Classic Study declined and waned in American colleges. Fueled by the interest in studying more contemporary texts, English Literature started to rise into prominence in the academia. The focus shifted from texts written in language devoid of native speaker to comparatively newer texts in comparison.

The study of English literature, however, proved to be derivative of classical study (Hobsbaum, 1992: 27 - 29). All the literary texts studied in the programme was treated similarly to the classical texts. They were considered merely as source materials to study the rules and other language-related sciences. What was called as English Literature was subordinated to the study of the English Language (Myers, 1993: 206; 2006: 16). English texts had to be studied and analysed with the same severe attention which is given to Greek and Latin classic. An example of this treatment can be exemplified by the curriculum for English at the University of Virginia in 1882 (Myers, 2006). The course would concentrate on four areas of study, such as (1) language structure; (2) correctness in speech and writing; (3) principles of style; and (4) the history of the language. The content of the texts itself was notably absent. This was, as Myers argues, due to the great influence of a positivistic Germanic ideal of linguistic scholarship. It is pretty ironic that a course emerging as an answer to the dissatisfaction to the older one turned out to be the same old ideal with a new packaging.

The creation of literature, Myers further argues, was halted. Campuses and universities around nineteenth century America offered merely a seat of literary learning and was less of a literary 
centre. One major element that dampened the impulse to participate in the creation process of new literary texts was the treatment of literary texts. They were subjected to tedious scholarly scrutiny. Literature was not seen as an important part of humanities and consequently the study itself was notably absent from the attempt to address a question 'what literature is for'. As Myers put it, "[t]hey studied the outside shell, not the thing itself." (ibid: 33)

Amidst this tendency for English Literature to grow into Classical Study part two, a movement to challenge this growth direction started to sprout. Creative writing emerged as one of the possibilities to address this issue (Mayers, 2009; Myers, 1993; 2006). It started off as an experiment in the education system in about 1880 s, carrying in itself an original goal to "reform and redefine the academic study of literature, establishing a means for approaching it 'creatively'." (Myers, 2006: 4). It intended to be a way of cultivating students' appreciation (Bildung) rather than a medium for producing and expanding knowledge (Wissenschaft) (ibid: 6).

The arrival of this new paradigm brought a new life to literary texts. Being rendered as 'a way' means that students had to 'walk' on that and at the same time enact their active participation. Texts are no longer just a medium - a one-way source of knowledge. Texts are transformed into living breathing bodies, open for students to participate in the creation/production of new texts, allowing growth to happen. These bodies of knowledge will continue to grow as long as the participation is sustained. Gone are days when literary texts were treated as stele/temple ruins in the hand of archaeologists. What was once a dead body lying on the autopsy table is now an organism full of life waiting to flourish. Literature has thus become a continuous experience and not mere corpus of knowledge (ibid; Andrews, 2009; Harper \& Kroll, 2008: 4; Mayers, 2009; Monteith, 1993).

The emergence of this new paradigm, however, gave birth to new questions and problems to be solved. Who would be eligible to teach and design the curriculum and instructions for Creative Writing? Creative Writing was born as the brainchild of the reformation to current literature teaching, as the anti-thetical movement against reigning philologic/linguistic-heavy approached in English Literature. It thus carried the burden of not repeating the same mistake its predecessor committed. The cause of philology domination in English Literature was the lack of people specifically trained in the new study. They were all trained in Classic Study and thus carried with themselves the torch for old paradigm. They had only a vague idea of literature study but no one was very sure what the study might entail (Myers, 2006: 21).

Despite the lack of people formally trained in creative writing during that period, history has proven the existence of creative writers throughout the course of human civilization. The banishment of creative guilds from university system did not drive them into extinction. They survived beyond academic scope as non-formal circle, giving birth to more and more creative writers. Their lack in academic qualification was compensated by their experience and publication history. They posses the knowledge gained and acquired through practical experience instead of sitting through numerous classes and reading piles of books.

At the same time - by the end of nineteenth century - literary life became professionalized. More and more writers started to dedicate their time fully for writing. It evolved from a mere call to do in their spare time into a dedicated craft. Shifting the attention to full-time writing, however, is not without any risk. It was, and still is, not a secret that most writers cannot live solely from writing based on their idealism. Most of those writers who chose to do so were left without visible means of support (ibid: 77). The only two choices that would still allow them the leisure of full-time writing were (and still are) bohemianism and the academic life.

With the opening of Creative Writing programs in the academic context, writers are searching for their patron in academe. They started flocking to various academic institutions to teach and pursue this alternative for life-support. Mayers (2009: 218) sees this and argued that Creative Writing is no longer just a program " $[\mathrm{t}] \mathrm{o}$ train aspiring writers to produce publishable works, to 
find success in the literary marketplace" but also "as a de facto employment program for writers who are unable to earn a living simply by writing." As a consequence, the selection criteria for this academic position cannot rigidly follow those of other disciplines. The writers were not hired based on their academic qualification, "writers are hired and promoted in academe on the basis of their writing - it has become their equivalent of original research" instead (Myers, 2006: 6).

It is important to highlight and remember that these writers came to the universities with quite different views from those of the other scholars. Their first and foremost focus lies in the craft of writing itself, the practical dimension of the field. Being practicians, some of them even showed no interest in conducting researches conforming to rigid academic rules. As a part of the academic context, however, the demand for research and publication is inevitable. These writers needed to satisfy this demand and to do so under the reigning paradigm of 'pure reason' that manifests in the idolatry of theories and the underestimation of pure arts practice. Pitted in this dynamics, another question emerges, how is the research dynamic in this practice-heavy field?

\section{Approaches and Methods in Creative Writing Research}

The research tradition in the academia has always been dominated by the linear mode of thinking perpetuated as an 'arborescent scheme'. It ranges from the classic Porphyrian trees, Linnaeus taxonomies, the models of the subject espoused by René Descartes, Hegelian 'Absolute Spirit, to Chomskyan sentence diagram (Bogue, 1989: 17, in Amorim \& Ryan, 2005: 582 - 3; Stagol, 2010: 14). This model is characterized by a rigid hierarchical system which centres to the significance and importance of a principal root (Deleuze \& Guattari, 1987: 16; Stagol, 2010: 14). The 'principal root' governs the growth of the whole tree, making sure that it mainly grows in a vertical-linear direction, creating different rank of superiority and importance among various parts of the tree (Stagol, 2010). The taxonomy and hierarchy it gives birth facilitated easy attempts to trace the source of this construct; linearity makes it easier to foresee the future direction of growth.

Creative Writing is, however now widely agreed to be anything but a linear process for most of those engaged in this activity (Harper \& Kroll, 2008: 4; Leggo, 2005: 442; Leavy, 2015: 78; Murray, 2004; Ryan, 2005: np; Sinner et al., 2006: 1242; Stewart, 2001, 2003). In creative writing, writers tend to gather and process the ideas for their writing from the awareness of surrounding world(s). The term 'awareness' itself implies holistic views and lateral perception, one with more than just one focal point. Consequently, there are more than just one process operating simultaneously. All these process generally follow recursive patterns. Stewart (2003) summarized the characteristics of this process as 1) impulsive; (2) unpredictable; (3) intuitive; (4) not always logical; and (5) difficult to analyse, interpret and describe.

With such a stark contrast between paradigms of research and creative practice, how could the creative writers adjust into the demand of academic research requirement? One of the feasible ways is through collaboration with some other research methods. Creative Writing tends to find easier collaboration with ethnography due to the latter's nature of being neither entirely linear nor completely objective as explained by Denzin (2006) below.

"Ethnography is not an innocent practice. Our research practices are performative, pedagogical, and political. Through our writing and our talk, we enact the worlds we study. These performances are messy and pedagogical. They instruct our readers about this world and how we see it. The pedagogical is always moral and political; by enacting a way of seeing and being, it challenges, contests, or endorses the official, hegemonic ways of seeing and representing the others." (Denzin, 2006: 422)

Ethnography later developed a new branch of research, autoethnography. In this branch, a significant shift of research focus from a wider, more objective phenomenon into a more personal experience takes place. It combines both 
subjective and objective narrated experience in the highlighted phenomenon. This shift leads autoethnography to become a turn towards blurred genres of writing, blurred boundaries between art and science, exploration of intersubjectivity, examination of power and authority issues including that of researcher/author, a heightened self-reflexivity, increased focus on emotion in the social sciences, and the postmodern skepticism regarding generalization of knowledge (Adams, Jones, \& Ellis, 2015; Anderson, 2006; Denzin, 2006; Glesne, 1997; Sturm, 2015; Vryan, 2006). These changes widen the opening for further collaboration between ethnography and creative writing.

While the collaborations might work well to satisfy the academic demand for research, some of the poems/texts created through the process lacks certain qualities from what the creative writers might regard as a successful writing. Most of the creative texts depend on the research context. They complement the research well, providing nuances and helping to flesh out the portrayed condition/ phenomenon, but they are weak outside the research report. Prendegrast (2009: xxxv) calls the poems as "a failed experiment that may function effectively for the purposes of the inquiry but does not sustain nor reward reader engagement as in successful poems."

While the creative products might not be satisfying from the creative perspective, the collaboration has proven an important premise for the development of creative writing research - that the act of writing can become an act of inquiry and research. In her book Method Meets Arts (2015), Patricia Leavy argues that there are some similarities and same principles underlying the operation of both academic inquiry and creative practice. Both are 'crafts' in their own respect. Researchers do not just gather the data and write - they have to think of how to present the data in their own way; they compose, orchestrate and weave the data into a presentable packaging (ibid: 17). From the artists' perspective, "[ $\mathrm{t}]$ he process of research becomes the practice, and because [they] are involved in a research process of thinking, evaluating and acting, the practice is a form of research" (Stewart, 2003: np). Both final products of research and creative practice also share the same aim; to illuminate, build understanding or challenge assumption of the readers/spectators. This puts both arts and research practices on the same ground instead of on contradictory polarity. Barrett (2007: 117), on the basis of Dewey's Art as Experience, highlights the point that knowledge itself is by definition experiential, whether it emerges from art or from science. It also means that art practices are granted the same eligibility with research practices in researching the world to enhance understanding, in conducting the inquiry (Irwin, Beer, Springgay Grauer, Xiong \& Bickel, 2006).

How does the knowledge formation take place in this practice? Departing from Dewey's experiential definition of knowledge, it is "gained by the artists through everyday living and activity, [...] instatiated into the artwork through creative practice" (Barrett, 2007: 117). By doing so, creative practice becomes a way of making sense of oneself, including one's relationships with others (Hecq, 2012). This practice is also accommodated by conceptualism, a form in ethnography (Adams et al., 2015). Within this framework, the act of writing is seen as performative, an act of doing. Thus, the process of inquiry and research is embodied in the writing itself. Personal stories are used as "the mechanism for conveying and critiquing cultural experiences" (ibid: 88).

With the heavier focus on self-experience, 'autobiography' emerges as a key concept in this practice-led research paradigm (Barrett, 2007; Leggo, 2008; Stewart, 2001 \& 2003). While many people might get the impression that writing about personal experiences can lead to narcissism, egoism, or even boring prattling, they are overlooking the fact that "our personal living is always braided with our other ways of living - professional, academic, administrative, artistic, social and political" (Leggo, 2008: 5). Autobiography allows portrayal of self, identity, history, time, narrative, interpretation, experience and knowledge of the artists that influence the development of ideas (Stewart, 2003). On one hand, this notion sounds similar to that of autoethnography. On the other hand, practice-led research places heavier emphasis on the produced 
creative texts than the accompanying exegesis essay.

As everyday living and activity makes up a big portion of creative practice, 'theory' in this research shifts into a 'living theory' (Irwin et al., 2006; Leavy, 2014; Leggo, 2008; Springgay, 2008: xxi; Stewart, 2003). Research becomes rendered as organic, a term defined as derivation from living organism or having and organization similar in its complexity to that of living things where everything is interconnected (Leggo, 1999). The setting for this research is a studio, which is seen as "an experimental area for creative interaction, a space for critical analysis and renewal." (Stewart, 2003: no page).

While some academes warmed up to this new research paradigm, some others argue against it. For these scholars, practice-based research is considered as the 'hasty academization of the creative practice community' (Biggs \& Büchler, 2007; Magee, 2012).

Practice-based research typically results in a bifurcation of its final product, a creative practice and the accompanying exegetical essay. This bifurcation has become a centerpiece for attacks from those arguing against practice-based research. For these scholars, neither of the products is capable to represent the result of the research. Magee (2012: 3 ) claims that while the research report aims to the production of a "single unified reader" experiencing and receiving the same message as anyone else, creative works cannot achieve the same thing. Creative works instead 'draws together an unusually diverse field of readers whose interests are located at various spaces of institutional discourse' (Brook, 2012: 1). Consequently, not all the readers can get or observe the new knowledge produced.

The accompanying exegesis essay for practice-based research is also under attack from Biggs and Büchler (2007). They argued that the documentation of creative process presented in the essay does not demonstrate 'rigor' in research. For them,

"[r] igor refers to the process of undertaking activities such as the literature research. It connotes a systematic and thorough research. As a result, the researcher can be confident that from a 'null return' (i.e., when the researcher's knowledge and understanding has been identified as absent from the published body of knowledge and understanding in the field), it can be concluded that the researcher's knowledge and understanding is new knowledge and understanding." (Biggs \& Büchler, 2007: 66)

Departing from that definition, Biggs and Büchler (2007; Brook, 2012) argues that rigor can only be judged through "the strength of the chain of reasoning, and that has to be judged in the context of the question and the answer' (ibid: 69). It is apparent, however, that their justification for rigor stems from the traditional arborescent scheme of research tradition where the flow of reasoning follows a linear trajectory. They failed to see that practice-based research has deviated from that linear direction and instead taking rhizomatic and ever expanding trajectory of thought. While their argument might be rendered right within the perspective of traditional research, the inability to consider rhizomatic trajectory makes this argument one-sided and unfair.

While its foundation on a rhizomatic trajectory opens up a space for creative practices, practice-based research also faces challenges in keeping up the balance. It does not have a strong excuse for favouring creative output and processes over academic texts. Brook (2012: 7) refers to this phenomenon as 'egotism and favouritism'. While exegesis essay is supposed to build upon a balance to the more traditional research paradigm, it is more often just description without any engagement with the existing theories. Even if it might reference/quote the theories, the level of academic involvement there is more often next to nothing. This lack of academic involvement causes practice-based research to be prone to attack to its validity and credibility as a 'research'.

It is, therefore, necessary to establish the bridge to foster balance and strengthen the position of practice-based research in the entirety of research realm. Ryan (2005) proposes the creation of a hybrid research method for creative practices (although she mainly addresses creative writing in her proposal) based on rhizomic research structure. This proposal also acknowledges the need of stronger emphasis on the theory as well 
as collaboration with various research strategies. As a defense from the domination of arborescent scheme, Ryan based her argument in the nature of emerging post-modernism as Kincheloe \& McLaren (1994: 143) point in the dissolution of traditional boundaries in the dawn of this new paradigm. Through this combination, Ryan foresees the emergence of not just both academic and creative result from the research, but also the fostering of creative praxis.

Ryan (2005), however, addresses the lack of clear beginning or ending of the process. While the cyclical nature is in line with the characteristic of a rhizomic structure, it potentially poses a problem for an appropriate research presentation style for the academia. Conclusion might be difficult to draw and thus the craving for academic closure for the research might be left insatiated.

\section{Approaching Rhizone}

Ryan's identification of problem in her proposed hybrid method - the cyclical nature and lack of clear beginning and ending - reveals an innate influence of arborescent framework, even in developing approaches to an acknowledged rhizomic structure. A clear beginning - or the principal roots - and the ending are still valued highly, illustrating the craving for a clear trajectory. It is thus necessary to have a research method/ practices built on the foundation of rhizome paradigm itself, the anti-structure.

In the original botanical context, rhizome is a root system that moves under the ground/surface with horizontal coverage and fascicular manner. It has the capability to 'attach itself to other root system and scatters in all directions' (van der Klei, 2002: 48; Colman, 2010: 232). One striking feature that differentiate rhizome from Porphyrian model is the absence of a principal root. The absence of the principal root as the control panel to the growth leads rhizomic root system to move in a unique characteristic illustrated by Deleuze and Guattari as follow:

'This time, the principal root has aborted, or its tip has been destroyed; an immediate, indefinite multiplicity of secondary roots grafts onto it and undergoes a flourishing development. This time, natural reality is what aborts the principal root, but the root's unity subsists, as past or yet to come, as possible.' (1980: 5)

The absence of 'principal root' consequently renders 'principality' obsolete in rhizome system. All parts are considered equally significant and of equal importance. Hierarchy is non-existing and taxonomy is purportedly absent. Instead of following a linear growth, rhizome grows in multiple directions; growing in multiplicity.

As it moves in planar and horizontal manner, rhizome grows in more axis than arboreal tree which is only going upward. Horizontal course of growth also imparts freedom of movement to the rhizome, allowing it to move unpredictably. This unpredictability and the inextricability that rhizome possesses consequently eliminates the definite starting point and end-point (Honan, 2007: 533). While this may cause confusions for people who think in 'arborescent scheme', the lack of definite starting point bestows freedom to enter the construct from any point one sees fit/openings (Springgay et al., 2005: 906).

Entering rhizome through any opening one sees fit is made possible by the interconnectedness of the scheme. Rhizome as the non-hierarchical concept is actually a map of networked, relational and transversal thought process (Colman, 2010: 233) and at the same time also 'a way of being without tracing the construction of that map as a fixed identity' (Deleuze \& Gaattari, 1987: 12). By just walking from the opening, one will be transported to 'the middle' of the construct. Deleuze and Guattari refer to 'the middle' as 'plateau' (ibid: 1). While borrowing Gregory Bateson's concept of 'plateau', Deleuze and Guattari modifies its original definition (as 'a continuous, self-vibrating region of intensities whose development avoids an orientation toward a culmination point or external end') into 'any multiplicity connected to other multiplicities by superficial underground stem in such a way as to form or extend a rhizome' (ibid: 2; Lorraine, 2010: 208).

As rhizome moves unpredictably from one plateau to another, every movement can be 
different. Mille Plateaux/A Thousand Plateaus has emulated this by demonstrating that one can go through the book by reading the chapters not in chronological order. What, then, influence(s) the direction? Irwin, Springgay and Leggo (2007: ix-x) explain that rhizome moves and flows in dynamic momentum and operates by variation, perverse permutation and flows of intensities that penetrate meaning. ' $[\mathrm{T}]$ he rhizome itself assumes very diverse forms, from ramified surface extension in all directions to concretion into bulbs and tubes' (Deleuze and Guattari, 1980: 7).

The main causes of diversity in forms assumed by rhizome are what Deleuze and Guattari called as “'deterritorialisation/reterritorialisation' (1983: 322; 1987: 88; Parr, 2010: 69-72). Both concepts refer to the shifting and reshaping of rhizomic form in the course of its movement. When rhizome moves from one plateau to another, it is being undone to prepare itself into entering a new territory. The planar and horizontal movement allow rhizome to penetrate and expand to various kinds of ground. Each ground has its own distinct characteristics. Coming back to the context of botany, different soil features will affect the plant growing in it. Even the same plant can have different characteristics had it grown in different soil/territory; e.g. coffee planted in Brazil will taste differently from the coffee planted in Java. But when one plucked the bean of Brazillian coffee and planted it in Java, the aforementioned bean is freed or deterritorialised from the Brazilian geographical condition. It may still retain some characteristics of Brazilian coffee, but when it is planted in Java, geographical condition of Java affects the growth of the bean. Thus reterritorialised, the coffee assumes a new set of characteristics depending of the new geographical condition.

\section{What is $\mathrm{A} / \mathrm{r} /$ tography?}

$\mathrm{A} / \mathrm{r} /$ tography is a methodology/approach created as an answer or tool to explore/map rhizomatic structure. It is an arts-based research practice that operates mainly within the frame of education/pedagogical research (Leavy, 2014; Irwin, 2013; Springgay, 2005; LaJevic \& Springgay,
2008; Springgay et al., 2008). Being constructed based on the concept of rhizome, a/r/tography addresses and accounts for multiplicities in and of the inquiry. The object of the inquiry is also seen and perceived as an assemblage - "a patchwork or ensemble that does not become a totality or a whole" (Roffe, 2010: 181).

The unusual typography in this method is a nod and homage to the multiplicities within the rhizomatic inquiry. The first three letters refer to three identities involved in the inquiry process, artist, researcher, and teacher. Under the umbrella of $\mathrm{a} / \mathrm{r} /$ tography, even the person doing the inquiry is seen as an assemblage, thus the multiplicity in the identity. Every encounter that each identity experience in the inquiry process affects other identities, rendering complex relation. Being grounded on the philosophy of rhizome, a/r/ tography considers it important to address this complexity instead of just focusing on a single perspective. The triumvirate of identities makes up the inquiry as an artist is actively 'creating' artworks, researcher attempts the act of 'knowing' and teacher is 'doing the teaching'. In other words, a/r/tographical inquiry is a combination of creation, knowing and doing (Leavy, 2014: 4). As a combination of arts, pedagogy and research practice, $\mathrm{a} / \mathrm{r} /$ tography hosts and gives space to these three practices to work together in the course of inquiry.

Being grounded on rhizomatic structure, the definition for each of the identities is also not strict. Springgay et al. (2006: xxv) highlight this flexible definition by saying that in the context of $\mathrm{a} / \mathrm{r} /$ tography, artists do not necessarily need to be someone who is making a living through art and educators/teachers do not necessarily need to be someone in the formal institution. The only requirement for artists is the commitment to "acts of creation, transformation and resistance" (ibid). The requirement for educators, Springgay et al. (ibid) explain, is "the commitment to educational engagement that is rooted in learning and learning communities through ongoing living inquiry".

Colliding arts and research practices leads both to share some attributes to facilitate smooth cooperation in the coming inquiry. Attribute 
sharing does not mean that these two different practices are melted together in creation of a new construct. While the term 'melting' might indicate the blurring distinction of arts and research practices in the production of an amalgam construct, the sharing process is more like a bowl of salad. Each element is still distinct enough to separate from the others, but they work together to produce a new unique 'taste'. One is not the interpretation of the other; both are manifested at the same time. A contiguous connection exists between these practices, allowing both practices to reverberate in vibrating movements - a constant movement that disrupts the traditional binary and defies linearity (Semetsky, 2003; Irwin et al., 2006; Livesey, 2010; Lorraine, 2010). This assembly of 'salad bowl' is referred to by Deleuze and Guattari (1987: 88) as 'assemblage' - a 'complex constellations of objects, bodies, expressions, qualities and territories that come together for varying periods of time to ideally create new ways of functioning' (Livesey, 2010: 18).

As a host of various multiplicities, assemblage logically possesses a space where one can reverberatingly navigate between each the constituting elements of the multiples - commonly referred to as 'line of flight' (Deleuze \& Guattari, 1987: 205, 503-4; Lorraine, 2010: 147). This middle space - some kind of liminal space - becomes the ground to conduct $\mathrm{a} / \mathrm{r} /$ tographical research; a space where the relations and combinations of each line of flight can be observed. In the context of $\mathrm{a} / \mathrm{r} /$ tography, some lines of flight can be identified as thought and materiality, theories and practices, identities, learning and experience, invention and interpretation (Irwin et al., 2006: 71). Although some of the identified lines of flight can be perceived as the product of Cartesian duality, they have been given new attributes in the spirit of rhizome and assemblage. Consequently, being located in such an interstitial space of assemblage leads the definition of theory to be interrogated. From the lens of $\mathrm{A} / \mathrm{r}$ / tography, theory is perceived as 'a critical exchange that is reflective, responsive and relational, which is continuously in a state of reconstruction and becoming something else together' (Springgay, 2008: xxi). Sharing the same attribute of constant becoming and being dethroned from the state of rigid inflexibility, theory is transformed from an abstract concept into an embodied living inquiry; it is materialized as 'an interstitial space for creating, teaching, learning and researching in a constant state of becoming' (Springgay, 2008: xxi; Irwin et al., 2006, Leavy, 2014).

With all the reverberation and vibrating movements taking place among lines of flight within the assemblage, the construct's movement becomes dynamic and unpredictable. Having shared attributes does not eliminate the differences among the lines of flight. The interactions of these lines are unique; the territory where the interactions take place also adds more variable to the computation in deciding the direction. Nobody can clearly predict where and how will this assemblage go. Therefore, to see and map the movement of this assemblage, one has to be immersed inside the construct. Being immersed itself requires active participation, leading the practitioner of $\mathrm{a} / \mathrm{r} /$ tography to observe while doing the practices of creation. In doing so, one should allow oneself to float in the randomness of this process flow.

"To be engaged in the practice of $\mathrm{a} / \mathrm{r} /$ tography means to inquire in the world through a process of art making and writing. It is a process of double imaging that includes the creation of art and words that are not separate or illustrative of each other but instead are interconnected and woven through each other to create additional meaning." (Springgay, Irwin, Kind, 2005: 899)

How can a/r/tography be related to Deleuzian rhizome? Irwin et al. (2007: ix-x) point out that Deleuzian rhizome is defined as 'an assemblage that moves and flows in dynamic momentum'. This definition is similar to the characteristics of $\mathrm{a} / \mathrm{r} /$ tography as discussed above. Because rhizome can attach itself to other root system (van der Klei, 2002: 48; Colman, 2010: 232), a/r/tography also possess the capability to attach itself into any rhizomic inquiry in order to map and see where will it go. Being a rhizome, however, puts $\mathrm{a} / \mathrm{r} /$ tography on a different ground from other research methodologies. A/r/tography accounts for the movement to all directions instead of following the linear, arboreal, hierarchical tracing commonly used by more traditional research methodologies. 
Without a seemingly organized and hierarchical order, a/r/tography 'starts' the inquiry in the middle. In fact, the lack of definite origin or end point gives license to $\mathrm{a} / \mathrm{r} /$ tography to start the practice in any point. After all, rhizome is an interconnected network/system in which everything is connected (Deleuze \& Guattari, 1987; Honan, 2007; Semetsky, 2003). It operates based on the principle of immanence (Williams, 2010) and Deleuzian adaptation of 'eternal return' (Spink, 2010). This means that $\mathrm{a} / \mathrm{r} /$ tography can reach any plateau through transformation into various forms and its capability to connect to almost anything in its way of becoming (Deleuze \& Guattari, 1987: 7). The constant transformation of $\mathrm{a} / \mathrm{r} /$ tography, therefore, demands high adaptability to changes and flexibility of the mind in responding to infinite shifts.

Being immersed in the movement of assemblage strips the power to control the journey of inquiry from the practitioner. There is no prediction or the concept of tracing in $\mathrm{a} / \mathrm{r} /$ tography. What one can do is to map the growth of this system (Irwin, 2013). Referring back to the possibility of infinite transformation of rhizome, $\mathrm{a} / \mathrm{r} /$ tography is consequently a constant work in progress. One can never reach the final destination of rhizome - for it lies in the infinite point that no man is able to see. Rhizome never stops to grow as long as human lives, cultures and universe continue to evolve. $\mathrm{A} / \mathrm{r} /$ tography is thus a 'living' inquiry.

\section{Sekar Macapat as An A/r/tographical Map}

'Multiplicity' is one of the key words and an important concept to handle in $\mathrm{a} / \mathrm{r} /$ tography. The complexity of multiple identities based on roles (artist, researcher, and teacher) in the inquiry process is acknowledged and accounted for. That multiplicity, however, is just one out of various other multiplicities entangled in the construction of one's identity. Taking myself as an example, I am an Indonesian PhD student (with both Indonesian and Javanese as mother tongues) in Macao who is engaged in various projects with people from different languages and cultural backgrounds - namely Indonesia, China, Australia, and Scandinavia. The language and cultural diversity that I encountered and experienced is undeniably an integral part in my process of 'becoming' artist, researcher, and educator in Creative Writing, especially in English. An a/r/tographical map is drawn as follow to illustrate the reverberation between these figments of identity. The moves back and forth among these aspects help and benefit non-native English speakers in their journey to become creative writers.

As $\mathrm{a} / \mathrm{r} /$ tography, the inquiry process is rendered as living inquiry through creative practices. Springgay et al. (2008) emphasise the importance of including experiences in the process of inquiry instead of just visual and textual understanding. The embodiment is done through the enactment of written and performative processes as 'a living practice of art making, researching and teaching' (Springgay et al., 2005: 902). Through the embodiment in the aforementioned practices, inquiry is given corporeal forms to manifest and continuously evolving (Colombat, 1991: 17). As the practitioner becomes a part of this corporeal inquiry, s/he will also influence and be influenced by the process - revealing a transformative attribute of $\mathrm{a} / \mathrm{r} /$ tography.

For this inquiry, the writing process of bilingual poems (in Indonesian and English) around Sekar Macapat - a traditional Javanese song cycle consisting of eleven poems - is used. Each of the poems in the cycle is a representation of different phases in human life. Traditionally, they have strict regulation for number of lines, syllables, and final sound in each line. The poems are (1) maskumambang or the fetal phase; (2) mijil or the birth phase; (3) kinanthi or the time when babies learn to walk; (4) sinom or the glory of youth; (5) asmaradana or the moments of love; (6) gambuh or the marriage; (7) dhandhanggula or the family life; (8) durma or the pain and sickness; (9) pangkur or the retirement; (10) megatruh or the time of death; and (11) pocung or the funeral.

As a complete cycle, Sekar Macapat has no clear opening or ending. In order to start the inquiry, $\mathrm{a} / \mathrm{r} /$ tography needs to be able to go into the structure and study it. An incision needs to be made to go into the structure and see what lies there. A/r/tography - in its inquiry - needs to keep 
performing these processes of cutting, going inside and stitching it back; it performs the process as living inquiry. Openings also mean the initiation of dialogues and new relationships as that is the aim of $a / r /$ tography instead of informing others what has been learned (Springgay et al., 2008).

In this inquiry, the opening was All Souls' Day. As Macao has a strong influence from Catholicism, All Souls' Day is celebrated as a holiday. The situation is different from Indonesia, where the aforementioned celebration is unknown for most people there. Being a poet, the holiday gave me an inspiration to write something about death itself. It was the opening to initiate the inquiry, as Macapat also places an importance to death through Megatruh. The title itself comes from two words, Megat (the act of divorcing something) and Ruh (the soul), thus focusing on the very last moment of separation. Following the strict regulation of Megatruh - five lines, with first line consists of 12 syllables and ended with the sound ' $u$ ' $(12 u)$ and eight syllables in the other four lines $(8 \mathrm{i}, 8 \mathrm{u}, 8 \mathrm{i}$, and 8o).

\section{megatrub}

litani panjang telah usai terlantun

di ujung mata dan hari

terbang kata dari mulut

menyisa amin di sisi

bagi nada tancep kayon

(trans.

a long litany has been recited

by the end of eye and day

words are flying away from the lips

only amen remains

to sing the last song of tancep kayon)

Through the poem, I rendered death from the perspective of Javanese culture, with reference to Wayang (shadow puppet performance). The performance is an important part in Javanese tradition. It is performed in various important celebrations in both personal life (circumcision, marriage, or other parties) and social celebrations (village thanksgiving or even rites of exorcism after natural disasters). It is also a common philosophy to compare oneself with the puppet, that human beings are just puppets played by the Almighty. Tancep kayon is a specific term to signify the end of the performance, when a special puppet called kayon is put at the centre of the screen. Even if the whole story has been concluded, the performance is not considered finished before the puppet master places kayon. Conversely, the puppet master can also deliberately place the kayon in the middle of the performance if he wants it and the performance will still be considered finished.

The creation of English version for this poem, however, is not done merely through translation. As the inquiry aims to map the reverberation between identities, a response poem from non-Javanese perspective was written instead. $\mathrm{A} / \mathrm{r} /$ tography as an inquiry practice allows the coming of sensibility through the ambiguity of in-between, where meaning is conceptualized through the anticipation of differences. It hints the meaning that is not quite there or yet unsaid. One needs to move between the pair to really see which meaning is constructed. 'There is both a loss of meaning and simultaneously a realization of it, invoking the presence of what it is not, and also what it might become' (ibid: 905). In Deleuzian framework, this denotes the process of 'deterritorialisation/ reterritorialisation' (Deleuze \& Guattari, 1983: 322; 1987: 88; Parr, 2010: 69$72)$. The shift between one half of the pair release the meaning from the influence of that half. It leaves the territory, enters the unfamiliar realm/ being de-automatised (Kelen, 2011). What is now de-automatised can assume new meaning when it penetrates the other half of the pair, entering a new territory (reterritorialisation). In this case, the traditional form that relies more on the sound play is transformed into a free verse poem with the core meaning intact. The new poem is as follow:

\section{megatrub}

death is the end of the longest prayer end of the day when heavy lids fall

death's beginning is like a prayer's too do words unheard sprout wings to fly? 
what is it that the tongue rolls off?

capture is evaded

only one word remains

in a pity of broken breath

amen gives itself up

to hearing

before the final

breathlessness

The response poem in English can also be translated back to Indonesian, creating a new poem about Megatruh. The process of deterritorialisation/ reterritorialisation facilitates the creation of several poems here.

maut menutup doa terpanjang di penghujung hari dan beratnya mata

serupa doa, awal kematian memberi sayap pada kata-kata tak sempat terucap

menghindari decak gulung lidah

melesat-lesat di antara makna

hanya satu yang tinggal dalam belas

kasihan nafas patah tersenggal

adalah amin yang merelakan diri

untuk diucap dan didengar

sebelum akhir

nafas

(trans

death ends the longest prayer

at the end of the day and the weight of eyes

just like a prayer, the beginning of death grants wings to the unsaid words

avoiding rolls of the tongues

flashing between meaning

only one stays behind in pity of broken breath

it is amen who sacrifices himself

to be said and to be heard

before the end

of breath)

While death is generally seen as the end of everything, Macapat accounts for anoher phase that happens after that. Pocung is a poem representing the funeral, the aftermath of death. While it is the end of one's physical existence in the world, it does not mean the end of one's influence to other people. Following the rendition of life as an art performance in the previous poem, I started to ponder the connection of poetry writing and the aftermath of death. One can still write something even after the death, a line or two written on the grave and thus forever associated with the person. This pondering leads into the creation of a following poem:

$$
\begin{aligned}
& \text { pucung } \\
& \text { the final song } \\
& \text { the last line } \\
& \text { in my longest poem } \\
& \text { one I will lose } \\
& \text { the right to claim } \\
& \text { it will be written } \\
& \text { on a seal of stone } \\
& \text { standing proud } \\
& \text { on a mound of earth } \\
& \text { stiff blanket } \\
& \text { for my longest sleep }
\end{aligned}
$$

Unlike Megatruh, the poem was first written in English due to the reference to epitaph written on the tombstone. It was not in the vein of Javanese culture to write the last word on the tombstone. In fact, due to the strong Islamic influence, the graves generally contain only names and date of 
birth and death. Due to this reterritorialisation process, the traditional rules for Pocung $(12 \mathrm{u}, 6 \mathrm{a}$, $8 \mathrm{i}, 12 \mathrm{a})$ is waivered.

The lack of inscription in Javanese graves does not mean that one's legacy is lost. While Islamic influence is strong, Javanese culture also retains strong elements from its primordial animism and dynamism. This duality leads into the existence of ancestors worship through the graves. People come and visit graves of their relatives or other important figures to ask for something. It is not uncommon for certain graves in Java to become a covert place of worship, with rituals being performed to ask for a favour from the spirit believed to reside there. From this perspective, the last line of the poem is thus not the inscription. The last line is the physical tombstone itself. Therefore, the Indonesian version of the poem is as follow:

\author{
pucung \\ - tembang terakhir - \\ larik terakhir di bait puisiku \\ tak digores pena \\ terukir pada abadi \\ nisan batu, menantang lembut udara
}

(trans.

the last line in my poem

is not written by pen

it is inscribed in the eternal life

of this stonehead, bravely facing the gentle sky)

The theme of death and afterlife in the creation process of Megatruh and Pocung continued to affect the progress. Not long after finishing Pocung, news about a bomb explosion in Indonesia came. The one and only victim in that event was Intan Olivia Marbun, a three-year old girl. Motivated by the news, the next poem was dedicated to her. Following the cycle rigidly is not possible since Maskumambang does not correspond to this event. Kinanthi, the poem about child's first step, is chosen to portray the irony of Intan's youth and early death. This seemingly random movement is allowed in the $\mathrm{a} / \mathrm{r} /$ tography, due to the flexibility of lines of flight. The construction of Macapat's body does not necessarily need to follow the order of poems, especially since encounter with the news/ events may change the directions of lines of flights anytime. The poem is as follow:

\author{
Kinanthi \\ third song \\ for Intan Olivia Marbun \\ her little feet \\ must now learn \\ to walk without \\ a mother's holding hand \\ that's how it seems \\ but is this so? \\ is it only blades of grass \\ her tiny hands can grab? \\ wild flowers that cheer \\ for another attempt \\ to rise up in giggles \\ does laughter remain \\ when tears are no more? \\ the bomb takes skin \\ takes pain in the end \\ it leaves all the time \\ not of this world \\ is that what she has now?
}

In reterritorialising the poem into Javanese/ Indonesian context, a lot of the elements in the English version needs to be compressed. While the English poem has 18 lines, the traditional form of Kinanthi only allows six lines $(8 \mathrm{u}, 8 \mathrm{i}, 8 \mathrm{a}$, $8 \mathrm{i}, 8 \mathrm{a}, 8 \mathrm{i})$. While the English version focuses on Intan's departure from the world, the Indonesian version refers to 'heaven'/'paradise' to accommodate stronger religious/spiritual sentiment in Javanese culture. 


\section{kinanthi}

- tembang ketiga -

untuk Intan Olivia Marbun

kaki mungil tak beribu

tertatih seorang diri

selepas bom di gereja

pekik pilu, jerit pedih

ia pergi ke hampar surga

menjelang damai abadi

(trans.

motherless feet

crawling alone

after the bomb at church

hysteric cry and emotional scream

she is heading to heaven

into eternal peace)

Throughout the writing process for the rest of Macapat, the movement continued to be similarly dynamic. Each encounter that the writer experienced changed the writing direction. Through this map for the beginning of the process, it can be seen how the rhizomatic movement and the use of $\mathrm{a} / \mathrm{r} /$ tography help facilitating my process of becoming a writer. "My" identity is embodied in the inquiry process, leading into the reverberation among 'I' as a Javanese, 'I' as an Indonesian, 'I' as an Indonesian abroad, 'I' as a student in English, 'I' as a non-native speaker of English, and various other 'I'. Each figment of this identity contributed in the creation of the poems. Each part of the identity experienced the 'deterriotorialisation/ reterritorialisation' and transformed into something new, leading into the assemblage of identity as a writer of this collection. The emphasis should be put in the specific context of this collection of poems, as with the process of writing up another collection, there will be different reverberation and encounters.

As a non-native speaker of English, the use of poetic form familiar to the context where I grew up provided more confidence. The play with sound to correspond to the dictated ending sound in each line was easier to do in my mother tongues. As illustrated above with the use of tancep kayon and various Javanese philosophies, there is more freedom to play with cultural reference. The act of play initiated in the writing of Indonesian poem continued in the English version, especially to find a way around the difficulty of sound play and cultural concept. What might be perceived as difficulties was transformed into a stepping-stone for further creative practices.

\section{Conclusion}

After being banished from the university system in favour of Enlightenment and its spirit of 'pure reason', Creative Writing saw its return to academia in the late $19^{\text {th }}$ century. Its seat was reinstated to answer the need for a new approach in the teaching of English Literature. Despite having English, a living language, as the focus, early stage of English Literature treated the language just like Classic Study treated Ancient Greek and Latin, a dead language. Creative Writing was brought back to breathe new life into the study, giving it a more productive aspect and more creative approaches to literature.

This return was not without its problem. Centuries of absence from the university system had caused the inexistence of academically trained creative writers. Professional writers were called to teach based on their creative works and experience instead of their academic qualifications. As parts of the academia, these writers were and are subjected to the academic demand for research. The research tradition, however, is mostly governed by the 'arborescent scheme' or linear mode of thinking. Creative process, on the contrary, is not a linear process. Being qualified from their identities as creative writers, these writers need to produce more creative works to maintain their positions. Having separate times for research and creative process is not an easy feat to do, thus combining both processes seems a feasible solution. Conforming to the existing research framework through collaboration with some other research methods is possible, but the creative works resulted from the research cannot stand on their own outside the research context. Conversely, the attempts to use creative practices as inquiry does not provide 
enough involvement with theoretical basis to satisfy the academic demand of rigor in research.

The situation calls for a compromise. New research methods are necessary to balance demands for rigor in research to the needs to produce more creative works. Ryan (2005) sees the emerging of post-modernism as an opportunity to merge creative practices and academic inquiry due to the dissolution of traditional boundaries. The merged result should not favour one over the other. The two previously clashing methods work together in creating a new entity in synergy. Forming a new entity also means attribute sharing, granting nonlinear or rhizomic characteristics to the academic inquiry.

One of the emerging methodologies capable of answering Ryan's proposal is a/r/tography. As a method (or as it prefer to refer to itself as a practice) developed based on Deleuzian rhizome, it centres around the concept of multiplicities. It considers itself as a unity of multiplicities, an assemblage - "a patchwork or ensemble that does not become a totality or a whole" (Roffe, 2010: 181). Not only providing a space where creative practice and academic inquiry can synergize, a/r/tography also acknowledges researcher's identities as artist, researcher and teacher. Having equal acknowledgement and the possibility to become all of them at once means less egotistical dictation to favour one over the other. It is one of the ways to reach balance between creative practice and academic inquiry.

As a rhizomatic structure, it is possible for the inquiry direction to take the unexpected turns and become unpredictable. Ryan's (2005) concern about the lack of clear beginning and ending reveals the possible problem for $\mathrm{a} / \mathrm{r} /$ tography from the traditional research's point of view. Thus, a new concept for research result presentation is needed as an answer to this problem. While the old tradition calls for the emphasis on the result, this new practice should put more emphasis on the process. The practice should also prefer to show the thinking process and the various unpredictable turns and encounter in its course. Consequently, mapping and describing become the preferred form over the traditional conclusive nature of other research methods.
Championing 'multiplicity', a/r/tography can also handle the complexity of identity in the inquiry. In the context of Creative Writing in English, a/r/tography is capable of mapping different creative process in ESL/EFL writers. Through the acknowledgement of various figments of identity, more and more creative processes and practices can be encouraged. The reverberation among various identities can work both in personal level or a wider context such as classroom context. Writer/teacher can conduct $\mathrm{a} / \mathrm{r} /$ tographic inquiry in multicultural classrooms (a concept starting to grow in the last several years due to the increase of international migration and refugee movement) involving different cultural backgrounds. In this way, both the person conducting the inquiry and the subjects can form an assemblage/community of practice.

While the report and presentation may end, the process and the journey continue. It means more creative works will be born, more academic inquiries will spring up, and more praxis will emerge. A map has been produced, but one can always take different routes even to go from the same points of beginning and ending, meeting different situation.

\section{Bibliography}

Adams, Tony E., Stacy Linn Holman Jones, and Carolyn Ellis. Autoethnography. Oxford ; New York: Oxford University Press, 2015. Print.

Amorim, Antonio, and Charly Ryan. "Deleuze, Action Research and Rhizomatic Growth." Educational Action Research 13.4 (2005): 581-594. Print.

Anderson, Benedict R. O'G. Imagined Communities: Reflections on the Origin and Spread of Nationalism. Rev. and extended ed. London ; New York: Verso, 1991. Print.

Anderson, L. "Analytic Autoethnography." Journal of Contemporary Ethnography 35.4 (2006): 373-395. CrossRef. Web. 11 May 2017.

Andrews, Kimberly. "A House Divided: On the Future of Creative Writing." College English 71.3 (2009): 242-255. Print.

Barrett, Estelle. "Experiential Learning in Practice 
as Research: Context, Method, Knowledge." Journal of Visual Art Practice 6.2 (2007): 115124. CrossRef. Web. 26 Feb. 2017.

Biggs, Michael, and Daniela Büchler. "Rigor and Practice-Based Research.” Design Issues 23.3 (2007): 62 - 69. Print.

Brook, Scott. "The Critiques of Practice-Led Research.” TEXT 16.2 (2012): 1 - 10. Print. Calhoun, Craig J., and Richard Sennett, eds. Practicing Culture. London; New York: Routledge, 2007. Print. Taking Culture Seriously.

Colman, Felicity. "Rhizome." The Deleuze Dictionary. Edinburgh: Edinburgh Univ. Press, 2010. 232-235. Print.

Deleuze, Gilles. Anti-Oedipus: Capitalism and Schizophrenia. Minneapolis: University of Minnesota Press, 1983. Print. . A Thousand Plateaus: Capitalism and Schizophrenia. Minneapolis: University of Minnesota Press, 1987. Print.

Denzin, N. K. "Analytic Autoethnography, or Deja Vu All Over Again." Journal of Contemporary Ethnography 35.4 (2006): 419-428. CrossRef. Web. 11 May 2017.

Glesne, Corine. "That Rare Feeling: Re-Presenting Research through Poetic Transcription." Qualitative Inquiry 3.2 (1997): 202-221. Print.

Gregorious, Zelia. "Commencing the Rhizome: Towards a Minor Philosophy of Education." Educational Philosophy and Theory 36.3 (2004): 233-253. Print.

Harper, Graeme, and Jeri Kroll, eds. Creative Writing Studies: Practice, Research and Pedagogy. Clevedon [England]; Buffalo [NY]: Multilingual Matters, 2008. Print. New Writing Viewpoints.

Hecq, Dominique. "Beyond the Mirror: On Experential Knowing as Research Mode in Creative Writing.” TEXT 16.2 (2012): 1 13. Print.

Hobsbaum, Philip. "The Teaching of Creative Writing." Teaching Creative Writing. Ed. Moira Monteith and Robert Miles. Philadelphia: Open University Press, 1992. 24 - 33. Print. Honan, Eileen. "Writing a Rhizome: An (im) plausible Methodology." International Journal ofQualitative Studies in Education 20.5 (2007): 531-546. CrossRef. Web. 11 Aug. 2015.

Irwin, Rita et al. "The Rhizomatic Relations of A/r/tography." Studies in Art Education 48.1 (2006): 70-88. Print.

Kelen, Christopher. "Community in the Translation/Response Continuum: Poetry as Dialogic Play." Collective Creativity. Amsterdam; New York: Rodopi, 2011. 281-298. Print.

"Process and Product, Means and Ends, Creative Writing in Macao." Beyond Babel: Exploring Second Language Creative Writing. Amsterdam; New York: John Benjamins Publishing Company, 2014. 75-102. Print.

Klei, Alice van der. "Repeating the Rhizome." SubStance 31.1 (2002): 48-55. CrossRef. Web. 25 May 2015.

Lave, Jean \& Wenger, Etienne. Situated Learning: Legitimate Peripheral Participation. Cambridge University Press, 1991.

Leavy, Patricia. Method Meets Art: Arts-Based Research Practice. Second edition. New York; London: The Guilford Press, 2015. Print.

Leggo, Carl et al. "Lingering in Liminal Spaces: $\mathrm{A} / \mathrm{r} /$ tography as Living Inquiry in a Language Arts Class." International Journal of Qualitative Studies in Education 24.2 (2011): 239-256. CrossRef. Web. 25 Mar. 2015.

"Research as Poetic Rumination: TwentySix Ways of Listening to Light." The Journal of Educational Thought 33.2 (1999): 112-133. Print.

"The Curriculum of Joy: Six Poetic Ruminations." Journal of the Canadian Association for Curriculum Studies 2.2 (2004): 27 - 43. Print.

"The Heart of Pedagogy: On Poetic Knowing and Living." Teachers and Teaching 11.5 (2005): 439-455. CrossRef. Web. 25 May 2015.

Livesey, Graham. "Assemblage." The Deleuze Dictionary. Edinburgh: Edinburgh Univ. Press, 2010. 18-19. Print.

Lorraine, Tamsin. "Lines of Flight." The Deleuze Dictionary. Edinburgh: Edinburgh Univ. 
Press, 2010. 147-148. Print. "Plateau." The Deleuze Dictionary. Edinburgh: Edinburgh Univ. Press, 2010. 208-209. Print.

Magee, Paul. "Beyond Accountability ?" TEXT 16.2 (2012): 1 - 19. Print.

Mayers, Tim. "One Simple Word: From Creative Writing to Creative Writing Studies." College English 71.3 (2009): 217 - 228. Print.

Monteith, Moira. "Creative Writing: A Historical Perspective." Teaching Creative Writing. Ed. Moira Monteith and Robert Miles. Philadelphia: Open University Press, 1992. 10 - 23. Print.

Murray, Donald Morison. A Writer Teaches Writing. Rev. 2nd ed. Boston: Thomson/Heinle, 2004. Print.

Myers, D. G. The Elephants Teach: Creative Writing since 1880. University of Chicago Press ed. Chicago: University of Chicago Press, 2006. Print.

. "The Rise of Creative Writing." Journal of the History of Ideas 54.2 (1993): 277. CrossRef. Web. 15 Apr. 2017.

Prendergast, Monica, Carleton Derek Leggo, and Pauline Sameshima. Poetic Inquiry: Vibrant Voices in the Social Sciences. Rotterdam, The Netherlands; Boston: Sense Publishers, 2009. Open WorldCat. Web. 15 Mar. 2017.

Roffe, Jonathan. "Multiplicity." The Deleuze Dictionary. Edinburgh: Edinburgh Univ. Press, 2010. 181-182. Print.

Ryan, Alyssa. "Connecting Two Research Strategies: A Hybrid Model.” TEXT 9.1 (2005): n. pag. Web. 2 Nov. 2017.

Sinner, Anita et al. "Arts-Based Educational Research Dissertations: Reviewing the Practices of New Scholars." Canadian Journal of Education 29.4 (2006): 1223 - 1270. Print. Semetsky, Inna. "Deleuze's New Image of Thought, or Dewey Revisited." Educational Philosophy and Theory 35.1 (2003): 17-30. Print.

Sennett, Richard. The Craftsman. New Haven: Yale University Press, 2008. Print. . The Culture of the New Capitalism. New
Haven: Yale University Press, 2006. Print. The Castle Lectures in Ethics, Politics, and Economics.

Spinks, Lee. "Eternal Return." The Deleuze Dictionary. Edinburgh: Edinburgh Univ. Press, 2010. 85-87. Print.

Springgay, $\mathrm{S}$. " $\mathrm{A} / \mathrm{r} /$ tography as Living Inquiry Through Art and Text." Qualitative Inquiry 11.6 (2005): 897-912. CrossRef. Web. 25 Mar. 2015.

Springgay, Stephanie. "An Ethics Of Embodiment, Civic Engagement and A/R/Tography: Ways Of Becoming Nomadic In Art, Research And Teaching." Educational Insight 12.2 (2008): n. pag. Web. 20 Mar. 2015.

Being with A/r/tography. Rotterdam:

Sense Publishers, 2008. Print.

Stagoll, Cliff. "Arborescent Schema." The Deleuze

Dictionary. Edinburgh: Edinburgh Univ. Press, 2010. 14-15. Print.

. "Becoming." The Deleuze Dictionary.

Edinburgh: Edinburgh Univ. Press, 2010. 25-27. Print.

Stewart, Robyn. "Practice vs Praxis: Constructing Models for Practitioner-Based Research." TEXT 5.2 (2001): n. pag. Print.

“(Re)inventing Artists' Research:

Constructing Living Forms of Theory." TEXT 7.2 (2003): n. pag. Print.

Sturm, Damion. "Playing With the Autoethnographical: Performing and RePresenting the Fan's Voice." Cultural Studies <-> Critical Methodologies 15.3 (2015): 213223. CrossRef. Web. 11 May 2017.

Vryan, K. D. "Expanding Analytic Autoethnography and Enhancing Its Potential." Journal of Contemporary Ethnography 35.4 (2006): 405-409. CrossRef. Web. 11 May 2017.

Webb, Jen, and Donna Lee Brien. 'Agnostic' Thinking: Creative Writing as Practice-Led Research." Working Papers in Arts and Design 5 (2008): n. pag. Web. 5 Mar. 2017.

Williams, James. "Immanence." The Deleuze Dictionary. Edinburgh: Edinburgh Univ. Press, 2010. 128-131. Print. 